\title{
CALVYN SE KERKREG EN INVLOED OP KERKE IN SUID-AFRIKA
}

Prof. B. Spoelstra

\section{HET CALVYN DIREKTE INVLOED OP DIE KERKREG IN SA KERKE ?}

Tradisioneel is gese dat Calvyn die vader van die Presbiteriale en selfs van 'n Presbiteriaal-Sinodale kerkregering was. In ons tyd word weer betoog dat hy 'n episkopaalse kerkregering voorgestaan het (vgl. bv. R. Boon, Apostolisch ambt en reformatie, 1965, Nijkerk). R. M. Kingdon sê nog weer dat die Calvinistiese sinodale kerklike organisasie en dissipline in Engeland sowel as in Frankryk rewolusie geïnspireer het. Geneve was die sentrum van „democratic centralization. Local planning and responsibility devolved in large measure on local consistories and colloguies that were elected at lease in part by the faithful of the local church" (Geneva and the Coming of the Wars of Religion in France 1555-1563. 1965 Geneva, p. 128). J. Bohatec (Calvins Lehre von Staat und Kirche, 1961, Breslau, p. 380) meen dat A. Kuyper by Calvyn se demokratiese gees aangesluit het. Tog kan met eweveel reg geargumenteer word dat Calvyn geensins ' $n$ demokratiese regeringstelsel in staat of kerk nie en allermins rewolusie voorgestaan het (vgl. A. van Ginkel, De Ouderling, 1975, Amsterdam, p. 145 v). Calvyn kan onmoontlik vir alle rigtings vader staan!

Ek kon geen werk vind wat Calvyn se gedagtes op kerkregtelike gebied betreklik geordend weergee nie. Sy denke is deur epigone waarskynlik meer gepretendeer as geinterpreteer. Talle kerkgemeenskappe sal op Calvyn as grondlegger van hulle kerkregering wil aanspraak maak. Weinig sal egter direkte invloed kan bewys. Via Engeland en Nederland het 'n reeks ander invloede (roomse, lutherse, rasionalistiese en liberale genootskapsreg) ook na SA deurgewerk. Om tipiese Calvyn-gedagtes in die verskillende Engelstalige of Afrikaanstalige kerkgemeenskappe binne SA tussen al die ander invloede uit te soek, is binne die bestek van hierdie referaat ' $n$ onbegonne taak.

\section{DIE MAG, WIL EN ORDONNANSIE VAN GOD AS GROND VAN} CALVYN SE REGSDENKE

Calvyn verstaan die begrip reg vanuit die soewereiniteit van God, Goddelike mag en geregtigheid word in God se Wil uitgedruk. Hierdie Wil word eerstens in die Heilige Skrif (regimen spiritualis) en tweedens in die natuurorde (regimen naturalis) geopenbaar. Kragtens Sy mag en outoriteit moet alle mense God reg eer en vrees. Die wil van God bepaal wat reg is en is die wet vir alle wette en vir ons lewe (Baur, 33v). God roep en gebruik daarom wêreldlike owerhede om die swaard of strenge reg te hanteer. Die regeerders het nie net regte nie maar as dienaars van God ook juis pligte (Jûrgen Baur: Gott und Recht im Werke Calvins, 1965, Bonn, p. 5-16;27-29). Die natuurorde is nie so ingrypend deur die sondeval aangetas nie. So toon die natuurreg, bv. ook dat God wil dat mense hulle ouers en burgerlike owerhede moet gehoorsaam wees. 
Calvyn beklemtoon liefde saam met reg. Naas die natuurwet is daar die sedewet. Die sonde verydel die sedewet (Baur, 54v). God se Wil (regimen spiritualis) is op herstel gerig. Die kerk is primêr vrug van herskeppingswerk deur die Woord en Gees van God. Gevolglik is die Kerkreg ius divinum (Baur, p. 29; vgl. Institusie en Roomse twee-swaardeleer; B. C. Milner, Calvin's Doctrine of the Church, 1970, Leiden, p. 58). Calvyn se uitgangspunt vir kerkregering is die bepaalde orde, ,because order is what Gods wills (ordinatio) and through His Holy Spirit effects.... Whereever the ordination and Spiritius Dei are correlated, there is order; where the Spirit works apart from the ordinatio Dei, there is the extraordinary". Wanneer die Heilige Gees Hom onttrek, volg daar „confusion and disorder" (Milner, p. 44c. Vgl. p. 134, h.a. Inst. IV, iii, 1; Calvyn, Kom. Heb. 5:4, Num. 17:4).

Die Heilige Gees bring die Ordinatio Dei in God se Woord en Wet by die mense tuis. Die wil of ordening van God skryf gevolglik kerklike ordening tot 'n groot hoogte voor. Die Wet leer die regverdigheid van God, openbaar ons eie onregverdigheid en beteuel die goddeloosheid. (B. C. Milner, p. 75, 81v).

In burgerlike en kerklike ordeninge moet ons daarom die wil van God erken en ons daarna skik. God openbaar hoe $\mathrm{Hy}$ gedien wil wees. Daarom het die kerk met die Woord van God, die Evangelie as wet van vryheid, te doen. In Gal. 5:1 verbied God dat soos die Roomse kerkreg gedoen het, gelowiges hulle vryheid ontneem word met bepalinge wat nie op die Skrif steun nie (J. Calvyn: Institusie, $I V, x, 8.10$. 11. 12. 13. 14. 15).

\section{CHRISTUS DIE HOOF IN DIE HEILIGE GEES IN DIE KERK AANWESIG}

Calvyn begin die Vierde Boek van sy Institusie: Ons kry deel aan Christus deur die geloof. Let wel: hy sê nie ons kry deel aan die kerk nie. Omdat ons swak is, is middele nodig om die geloof te werk en te vermeerder. Daarom het God herders en leraars verordineer om ons te onderwys en om die sakramente te bedien. Gevolglik moet hy in die Vierde Boek handel oor die kerk, kerkregering, ordening, mag, sakramente en burgerlike orde. Dus begin hy met die universele onsigbare kerk wat God uitverkies het.

In die kerkregering sluit die ordinansie of wil van God basies menslike bepalinge uit. Die wese van die kerk is geloofseenheid en nie instituut of organisasie nie (Bohatec, p. 563-565). Anders gesê: die wese van die kerk is vir Calvyn geestelik. Die geloof gee deel aan Christus (Inst. IV, i, par. 1). Hy reken nie primêr met "lidmaatskap" van die kerk nie. Die kerk is net middel (moeder) om die gelowiges te vergader, te voed en te regeer. Die Heilige Gees gee geloof in die Evangelie aan die uitverkorenes. Hy roep hulle en plant hulle in die kerk saam met ander in Christus. Daarom word die kerk sigbaar waar die Woord gepreek word en die Heilige Gees daarmee werk. Die ordinatio of wil van God laat die verbond van God, die gemeenskap in Christus in die sigbare kerk, op unieke wyse naas burgerlike ordeninge daar wees (Inst. IV, i, par. 3). Die prediking van die evangelie en leraarsamp ,konstitueer" of insti- 
titueer dus feitlik die vergadering van gelowiges as kerk (Inst. IV, i, 5; Vgl. Milner, p. 48, 53v).

Sohm doen Calvyn onreg aan deur te beweer dat hy soos Rome van die sigbare kerk met regsvorme (Rechtskörper) uitgegaan het en die goddelike bygeroep het om sy institusionele regsordening te steun (Bohatec, 563-565). Die wonder is juis dat die uitnemende juris, Calvyn, nie 'n ,,konstitusie" ontwerp het en so 'n ,kerk gestig" het nie. Anders gesê: Die kerk is vir Calvyn in sy wese organisme en nie instituut nie, al het die organisme 'n institusionele patroon.

Calvyn beskou die kerk in absolute sin vanuit Christus as die enigste Hoof uit wie die hele liggaam saamgevoeg en saamverbonde 'n eenheid vorm (Kom. Ef. 4:16; Inst. IV, vi, 9). Die kerk is pneumatiese organisme. Die verhoogde Christus werk tweeërlei: direk waar Woord en Gees optree en middellik waar die verhoogde Christus in die Heilige Gees hom bedien van mense sodat die kerk, Sy liggaam, die gemeenskap van Christus sigbaar na vore tree. „Darnach Gestaltet Sich das Recht in der Kirche. Es ist das Recht Christi, das sich auf den ganzen Kirchenkörper und jeden einzelen erstreckt, und, da Christus durch seinen Geist und sein Wort wirkt, als Wortrecht und Geistesrecht bezeichnet werden kann. Weil es in Christus und seinem Wort verwurzelt, so sind alle von ihm geregelten kirchlichen Ordnungen pneumatisch. Darum ist die Kirchen Verfassung pneumatisch .... Das Ordnungsrecht der Kirche ist daher kein weltliches Recht, keine juristisch zwingende Gemeinschaftsordnung, sonderen ein pneumatisches Ordnungsrecht.... kurz die Regel des Organisch-pneumatischen Wollens in der Kirche...." (Bohatec, 570v). Milner sê: „The unifying principle in Calvin's Theology is .... the absolute correlation of the Spirit and the Word: it is the inseperability of the Spirit and the Son.... When the work of the Spirit is correlated with those manifestations of the Word (ordinantiones Dei), order-above all the order which describes the church, appears. Thus the church (order) can only be understood dialectically, as referring simultaneously to the Word and to the Spirit ...."

Vir Calvyn kom alle kerkregering op die bediening van die Woord van Christus en op die opbou van die liggaam van Christus neer. Eenheid in Christus kom na vore waar die leer suiwer bewaar, godvrugtig gelewe en die broederliefde beoefen word. Waar hierdie eenheid van die gelowiges met hulle Hoof, Christus versorg en verdiep word, word die kerk, die liggaam van Christus, opgebou. Die gelowiges word innerlik vernuut (Milner, 172). Die heerskappy (koninkryk, koningskap) van Christus word so geestelik in die kerk verwesenlik (Inst. IV, i, 9; ii, 4). Dit is die vrug van die Heilige Gees (Inst. IV, i, 6).

\section{GEESTELIKE (KERKLIKE) EN POLITIEKE (BURGERLIKE) REGERING}

Op sterkte van die wil van God onderskei Calvyn unieke sfere van wêreldlike en kerklike regering (vgl. Inst. III, xix, 15; IV, xx, 1). Die moderne begrip "staat" is aan Calvyn onbekend. Vir Calvyn het God 'n bepaalde persoon(e) geroep om sy Wil uit te voer 
(Inst. IV, xii, 4.6). Regeerders is stadhouers van God, Dei legati. Gevolglik het owerhede nie regte nie, maar pligte (vgl. Baur, 39v, $117,120)$. Die owerhede moet gevolglik self die Tien Gebooie (Wet) en Wil van God gehoorsaam (Baur, 71, 267).

Calvyn het in 1541 vir sy terugkeer na Genéve as voorwaarde gestel dat die Raad die selfstandige reg van die kerkdienaar sal erken om geestelike dissipline uit te voer. Hy moes egter met die Geneefse Klein Raad, Raad van Twintig en die Raad van Tweehonderd reken. Die owerhede het die reformasie deurgevoer en hulleself as kerkvoogde en erfgename van die vroeëre gesag van die biskop, pous of vors beskou (vgl. Boon 176v; J. Plomp, De Kerklijke Tucht bij Calvijn, 1969, Kampen p. 181).

Volgens Calvyn stel God se wil grense vir die gesag van die owerheid (Bohatec, 12). Onder owerheid word die persoon verstaan wat regeer. Gelowiges kan selfs verplig wees om die willekeur van 'n owerheid met passiewe weerstand o.l.v. mindere owerhede teë te gaan. Calvyn wys rewolusie radikaal af. 'n Monargie lei maklik tot tirannie terwyl 'n demokrasie deur die wil van die massa tot onbestendige regering en anargie lei.

Die burgerlike regering moet vryheid daar stel sodat die samelewing orde en welvaart ooreenkomstig die wil van God kan belewe. Daarom moet die owerhede openbare goddeloosheid teengaan en liefde selfs in die burgerlike samelewing geld (Inst. IV, xii, 2.3.8.15; IV, $\mathrm{xx}, 31$ ). Gehoorsaamheid aan die owerhede is egter ook gehoorsaamheid aan God (Inst. IV, xii, 22; Baur, 135, 137, 141). Burgerlike en kerklike owerhede tree op soos die twee oë van die liggaam. Hulle is in God verbind en moet mekaar wedersyds erken en aanvul.

Calvyn se teokrasie gaan van die heerskappy van God se Wil uit. Tog verskil hy radikaal van die Roomse opvatting. Hy ken geen priesterheerskappy oor politieke owerhede nie. Hy verwerp hierokrasie sowel as caesaropapie (Baur, 267). Die owerhede is nie aan die kerklike dienaars nie maar slegs aan die Woord onderworpe. Die predikant is nie eksklusief baas oor die Woord nie en het slegs prioriteit t.o.v. die owerhede (as persone) om die Woord uit te lê. Elke gelowige is egter ook mondig en kan met die Woord oordeel oor predikante. Calvyn wys 'n staatskerk af (Baur, 269), maar beoog om deur die koördinasie van die kerklike en burgerlike roeping die vrye burgerlike gemeenskap van Genéve "stadskerk" en ,volkskerk" te maak. Die Libertyne het dit as inbreuk op hulle vryheid beskou (Doumergue: Calvyn in de Strijdtperk, 203v).

Calvyn keur af dat dieselfde persoon 'n kerklike (geestelike) en burgerlike (wêreldlike) regeeramp gelyktydig beklee. In sy amp as geestelike opsiener en predikant het hy voluit die burgerlike owerheid geadviseer en met hulle saamgewerk, maar hulle dra die verantwoordelikheid vir hulle besluite. Ewe-so kan die Raad weer konfessionele en dissiplinêre vrae aan die konsistorie voorlê, maar die konsistorie moet oor kerklike sake en dissipline in eie reg besluit. Die owerhede oefen regspraak oor misdade uit. Die kerkraad besluit oor ekskommunikasie van nagmaal en kerklike gemeen- 
skap (Plomp, 151, artikels van 1537; Baur, 145-147). Kragtens die destydse idee van die corpus christianum in Genéve moes die kerkraad ekskommunikasie by die Klein Raad aanmeld, waarna die persoon gewoonlik burgerlik ook uit Genéve verban is.

\section{CALVYN SE UNIEKE BYBELSE KERKBEGRIP}

Calvyn se unieke kerkbegrip verskil radikaal van miskien alle kerkbegrippe wat tans in omloop is. Die begrip „kerk" word vandag oorwegend klerikaal, kollegialisties (genootskaplik) en institusioneel verstaan. Die kerk is vir Calvyn egter wesenlik organisme. Indien ,kerk" tans oorwegend as instituut verstaan word, kan die SA-kerkgemeenskappe moeilik op invloed van Calvyn in hulle kerkregering aanspraak maak. T.o.v. die leer mag die geval anders wees.

Die kerk is kragtens sy wese 'n eenheid

God verkies die gelowiges wat die kerk is tot die ewige lewe. Kragtens die wil van God bring die Heilige Gees (in Wie God die Vader en Seun op aarde werk) die gelowiges wat die Vader verkies en deur die Woord geroep word tot geloof. Deur die wedergeboorte lyf die Heilige Gees die gelowiges in die liggaam van Christus in en bou ,eine Einheit in der Vielheit, die erhalten und belebt wird durch das eine Haupt Christus" (Bohatec, 270). Die kerk is wesenlik ,einen Organismus, dessen Ursprung und Ziel in der Ewigkeit liegt.... Dieser mystische Körper.... ist eine Wirklichkeit, kein blosses Schema oder Bild" (Bohatec, 267).

Die geestelike innerlike eenheid wat die kerk is, tree na vore in dieselfde belydenis (al is dit net ooreenstemming in hoofsake, Inst. IV, 1.12), broederliefde en gehoorsaamheid aan die Wil (Woord en Wet) van God (Inst. IV, ii, 5.9.10). Daarom breek die Reformasie met die pousdom, maar Calvyn weet dat daar ook nog ware kerke onder die druk van die pousdom oorbly (Inst. IV, ii, 12). Skyngelowiges en ongelowiges vermeng hulle op aarde met die kerk wat God ken (Iist. IV, i, 7.13; Baur, 143). Die kerk as gemeente van gelowiges is verplig om in gehoorsaamheid aan die Woord en Gees die geloofs- en lewenseenheid met gepaste dissipline uit te oefen. So bewaar Christus en nie die kerk nie die eenheid (Bohatec, 419).

Calvyn ontken dat Christus 'n kerklike organisasie of instituut nodig het om die kerk in eenheid te hou (Inst. IV, vi, 10). Waar Luther Christus as Hoof van die onsigbare kerk gemaak het, laat Calvyn Christus ook konkreet in die sigbare kerk heers in sover die Woord regeer (Inst. IV, ii, 4, viii, 1; Bohatec, 399v). Die kerk is een. Christus het immers per definisie net een liggaam en Hy alleen is koning van die kerk.

\section{Die kerk is pneumatiese en dinamiese organisme en nie statiese instituut nie}

Teenoor Rome vir wie die kerk priesterinstituut is, stel Calvyn dat die liggaam van Christus en die koninkryk (heerskappy van God) in die gemeente (kerk) sigbaar word. Die gemeente is kerk van Christus in so ver die Woord en Gees gehoorsaam word. Die kerk is nie in die biskoppe en konsilies sigbaar nie, maar in die eenheid van gelowiges (Bohatec, 292). Wie dié eenheid verbreek, 
verloën God en Christus (Inst. IV, i, 3.4.5.6.10). Die eenheid van die kerk is gevolglik nie staties-institusioneel nie (Bohatec, 346v), maar organies-dinamies omdat dit voortdurend as eendragtigheid in geloof en lewe bewaar en vergestalt moet word. Gevolglik is die kerk daardie eenheid waar die Woord van God suiwer gepreek en (L.W.) gehoor en die Sakramente volgens die instelling van Christus bedien en (L.W.) ontvang word (Inst. IV, i, 8.9.10; vgl. B. Spoelstra, Calvyn en die grense van die kerk, In die Skriflig, 1978, nr. 45 p. 20v).

„One cannot persue the study of Calvin's doctrine of the church without being struck by his repeated usage of such metaphors as assimilate the church to an organism, i.e. to a created, living, historically evolving reality...." (Milner, 7). Die verhouding van die mens tot Christus, die liggaam tot die Hoof, bepaal dat buite die kerk geen saligheid is nie (Inst. IV, i ,1.2.3; Bohatec, 351). Hierdie eenheid met Christus kan nie met statiese uitwendige lidmaatskap aan 'n instituut vereenselwig word nie. Kragtens die wese van geloof is die eenheid met Christus ,,something which happens again and again" (Milner, 180, vgl. Komm. Joh. 11:51, Jes. 37:26).

Die koningskap en liggaam van Christus is Calvyn se „deepest and most concrete understanding of the church". Woord van Christus en Heilige Gees mag nooit geskei word soos Rome en die Anabaptiste gedoen het nie (Milner, 190v). Die kerklike organisme leef dus in "dynamische Mystik, eine Mystik der Tat, eine operative Mystik" (Bohatec, 351). „The church (order) must always be understood, therefore, as existing in the movement from the believer to the Word which occurs in the leading of the Spirit through ordained means. As a movement of the Spirit the church cannot be regarded as a static fixed entity, even if it has a certain stability and continuity as a movement of the Spirit through ordained means" (Milner, 192).

Die geestelike organisme, kerk, leef primêr in die gelowiges omdat God hulle verkies en geroep het tot diens in alle vertakkinge en uitinge van die totale lewe. Die bediening van die Woord (in prediking, sakramente, onderwys, pastoraat en tugoefening) bevorder slegs hierdie roeping om God te dien en maak nie die wese van die kerk uit nie. Tog het die kerk vir Calvyn net soos vir Luther nie 'n ,offentlich-rechtliches Genossenschaft" of „Körperschaft im enger Sinne" nie (Bohatec, 377-379). Calvyn noem "die institutionelle Imperialismus der Kirche" tirannie wat met die antieke Romeinse wêreldheerskappy ooreenkom (Bohatec, 442).

\section{Die kerk is konkreet sigbaar in die nagmaal.}

Die kerk verskyn uiterlik waar die nagmaal gevier word (Bohatec, 276, 280). „God has ordained both the preaching of the Word and the administration of the sacraments, and when coupled with the efficacious working of the Holy Spirit they constitute the order which marks the reality of the church.... According to Calvin, then we cannot think of the church as a legally defined institution .... nor can we conceive it mystically.... Rather, the church must be defined dialectically as union with Christ in, through and together with the means by which the Spirit brings us to Him...." 
(Milner, 123v). Die nagmaalsgemeente is derhalwe die ideale gestalte van die eenheid van die gemeente met die Hoof, Christus (Bohatec, 339). Die dissipline rondom die nagmaal (vgl. Inst. IV, xi en xii met Dordtse KO 1619 art. 16, 23, 61, 76, 78) beliggaam die Calvynse tradisie. Ekskommunikasie van die nagmaal is die wese van kerklike dissipline.

Calvyn definieer die kerk gevolglik konsekwent as liggaam van Christus (Art. 27 tot 32 Conf. Belgicana bied Calvyn se kerkbegrip). Milner merk tereg op dat Calvyn se navolgers egter die kerk in terme van "new construction, membership drives, programmes budgets and the like" gaan omskryf het omdat hulle Calvyn se eenvoudige en natuurlike kerkbegrip onverskillig bejeën het. Milner sê dat ,in working with Calvin's doctrine of the church I was.... being led straight into the centre of his thought" (Milner, ix).

Die kerk word formeel gestruktureer waar elke gelowige die Geloofsbelydenis onderskryf. Geloofsbelydenis verleen toegang tot die nagmaal en is in Genéve ook grondslag vir die stadsvolk gemaak. Die burgery moes „,bewuste belijdende volkskerk” wees. Die owerhede moes die kerklike dienaars hierin ondersteun sonder dat hulle daarmee ius in sacra verkry het (Plomp, 150). Die Hervormers het reeds op 16 Januarie 1837 aan die Klein Raad in Genéve die onlosmaaklike saamhang van belydenis en nagmaal gestel (Plomp, 145v).

"The conception of the church as the restoration of order in the world means that the church cannot be apart from the world, or as a secure corner of redemption in it.... Calvin's political activism, then may be traced directly to his conception of the church as that movement which stands at the frontier of history, beckoning the world towards its appointed destiny". (Milner, 195). Die gemeente wat een met Christus in die Belydenis is en in die nagmaal na vore tree, staan dienend midde in die lewe. Die Evangelie (en kerk) staan en val by die waardige viering van die nag. maal en die handhawing van die kerklike dissipline deur ekskommunikasie van die nagmaal (F. W. Kampschulte, Johan Calvin. Seine Kirche und Sein Staat in Genf. Herdruk 1972, Geneve, 284-287; Doumergue, 197-199).

Die kerklike mag van Christus word primêr deur die kerk (gelowiges) bedien.

Die kerk het gesag waaraan niemand hom ligvaardig mag onttrek nie (Inst. IV, i, 10) omdat die Woord en Sakramente die kerk bepaal en God daar self aanwesig is in die Gees (Inst. IV, i, 9, 11). Op sterkte van Mat. 18:15v. leer Calvyn dat die kerklike dissipline en tug met die onderlinge vermaning van die gemeente geskied. Die kerk handel later o.l.v. die ouderlinge (Inst. IV, i, 22; xii, 1.2) om die doel van die kerk (Inst. IV xii, 5.7.11) te bereik (vgl. Komm. 1 Kor. 5, 12 en 14). Hoewel Calvyn hier met teësin om praktiese redes tussen clerici en gelowiges onderskei (Plomp, 250v), bepaal sy kerkbegrip (Christus-en-sy-liggaam in die sigbare kerk) sy opvatting dat die kerk (gemeente) met tug van die Woord en Gees die regering van Christus tot uitvoer bring. Idependentiste en Baptiste het hierdie unieke en onherhaalbare plek van die gemeente 
(kerk) probeer vashou. Ander het die regering van Christus met die kerkraad (of sinode) verplaas en sodoende die unieke aard van Calvyn se vertrekpunt in kerkstruktuur verlê.

Elke gelowige word deur die Heilige Gees gelei en aanvaar die Woord. Die gelowiges (kerk) moet dus ook oordeel of die prediking van predikante van die Heilige Gees uitgaan, ooreenkomstig die Skrif geskied en of daar menslike versinsels aan toegevoeg word. Predikante durf nie aanstoot neem wanneer hulle aan die Skrif getoets word nie (vgl. Kommentare 1 Tess. 5:32; 1 Kor. $14: 29$, 32; Matt. $18: 15 \mathrm{v}$ ens.). Calvyn hekel die Roomse klerus se aanspraak om gehoorsaam te word wanneer hulle self aan die Woord ongehoorsaam is. Plomp maak die stelling dat die gemeente reg en plig het om mee te spreek in kerklike sake (Stelling XIII). Die kerkvolk moet elke kerklike ampsdraer in geloof en leer beoordeel, goedkeur en aanvaar (Boon, 90, 104). Al lei die kerklike dienaars verkiesinge, die gemeente moet die verkiesing goedkeur (Bohatec, 477-488). Sonder die kerk sluip tirannie soos in die Roomse Kerk binne en sonder die leiding van herders val die gemeente in anargie en chaos soos by die Dopers uiteen (Bohatec, 493v). As deurtrapte aristokraat temper Calvyn die "demokrasie" deur die leiding van die kerklike dienaars, maar hy skakel die gemeente in geen handeling uit soos vandag so baie gebeur nie.

In wese glo Calvyn dat Christus sowel deur die gemeente as deur die instrumente wat $\mathrm{Hy}$ gebruik die kerklike mag uitoefen. Kerklike mag is dus een en dieselfde gesag van Christus en nie 'n mag wat uit volkswil of uit mandaat van 'n amp of vergadering opkom nie. Bohatec praat van die integrasiemotief, die eenheid van die liggaam, wat steeds Calvyn se denke beheers (Bohatec, 421v). Kampschulte (p. 396) sê ten regte dat Calvyn die gemeente as vertrekpunt neem en elke opvatting bekamp wat die kerk in die vergadering van pastore soek. Laasgenoemde sê ten onregte dat Calvyn tog ook maar die geestelike amp van die gemeente skei, wanneer beide dieselfde gesag van Christus bedien.

In elke stad is die kerk van Christus in een volks- en stadskerk aanwesig, wat in verskillende stads- en distrikswyke fungeer. Calvyn het in Straatsburg egter op etniese gronde wat Plomp (157) 'n „vrywilligersgemeente" langs die "volkskerk" noem, bedien.

\section{DIE VIER DIENSTE OF AMPTE}

Christus bedien self sy kerk deur die dienste

W. D. Jonker (Om die Regering van Christus in sy Kerk, 1965, p. 6v) raak die kern wanneer hy aandui dat die Reformatore net soos Rome die opsiener (biskop) as verteenwoordiger van Christus by en in sy kerk (gemeente) neem. Rome ken kragtens die amp regeermag aan die biskop toe met die bewering dat hy in die amp deur die Heilige Gees gelei word (vgl. Kampschulte, 404). Calvyn bind die amp aan bediening van die Woord. Die Here alleen regeer sy kerk en wel deur sy Woord, sê Calvyn. Hy woon egter nie in sigbare gedaante onder ons om sy wil aan elkeen bekend te maak nie. Hy gebruik hiervoor die diens van mense. Hy leer ons om nie op die draer te sien nie, maar op die skat wat hy bring (2 Kor. 
$4: 7)$. Die onderwys van die herder met die Woord voed die onderlinge liefde en dra die gemeenskaplike leer oor binne die een liggaam van die een Gees oor (Ef. 4:4v). Die bediening van die Evangelie deur mense is die vernaamste senu waardeur gelowiges met mekaar in een liggaam verbind word. Sonder herders en leraars kan die kerk nooit wees nie. (Inst. IV, iii, 1.2.4.). God roep ' $n$ dienaar in en tot 'n bepaalde gemeente waar hy God in die Woord wat hy verkondig en die heilige sakramente wat hy bedien, verteenwoordig (Kampschulte, 401). Hierdie dienaars moet "pneumatische Persönlichkeiten" wees sodat God en Christus self in die Heilige Gees deur hulle diens in die gemeente werk (Bohatec, 425, 427; Kampschulte, 329). Gewigtige handelinge moet daarom altyd eers na gebed geskied (Bohatec, 431).

Diens in die kerk geskied kragtens roeping van God en bevestiging deur die kerk

Die dienaars wat God gebruik, ontvang nie hulle opdrag van 'n kerk, kerkraad of die Raad in Genéve nie. Die gemeente moet weet dat God self dienaars (ook ouderlinge en diakens) innerlik roep, hulle taak bepaal en hulle toerus met die Heilige Gees (Inst. IV, iii, 10-16). Hy bevestig middellik deur die gemeente die innerlike met 'n uiterlike roeping wat uiteenval in verkiesing, goedkeuring en seremonie van bevestiging. Die handoplegging druk uit dat hierdie dienaars onder opdrag van en in direkte verhouding tot God moet dien. Christus en sy liggaam, die kerk, is een. Daarom is dienaars tegelyk verteenwoordigers van Christus en van die kerk op voorwaarde dat die "durch das Wort wirkende Christusgeist in ihr herrscht" (Bohatec, 498. Vgl. Bohatec, 470v; Kampschulte, 398v; Boon, 90, 104v; Doumergue 336v). In Genéve het die Kleine Raad egter die predikante en ouderlinge aangestel (Plomp, 189). Calvyn noem dit 'n smaad vir die kerk (Inst. IV, v. 3).

Calvyn neem dus die geroepe presbiter-opsiener of biskop en nie die kerkraad nie as uitgangspunt in die kerkregering. Calvyn ken nie 'n presbiteriaal-sinodale kerkregeringstelsel nie (Boon, 221v). Tereg sê Boon dat die epigone van Calvyn sy kerkreg in teenstrydighede en onduidelikhede laat vasloop het wat tot „voortschrijdende desintegratie" in die gereformeerde kerke gelei het. Baptiste en sektes neem die gemeente onder 'n biskop (opsiener) as vertrekpunt en leef daarom baie meer dinamies as wanneer die ,irreële theorie" van die kerk as sinodale eenheid uitgangspunt vorm (Boon, 193, 204v).

\section{Die herder, bedienaar van die Woord of biskop}

Calvyn het in die eerste uitgawes van die Institusie en sy eerste kerkinrigting in Genéve 1537-1538 feitlik net die diens van biskop of bedienaar van die Woord, bygestaan deur die hulpdiens van diakens geken (Bohatec, 451). A. van Ginkel (117) toon aan dat Calvyn sonder ouderlinge in Straatsburg tug uitgeoefen het. Hy het geoordeel wie tot die nagmaal toegelaat word (vgl. Inst. IV, i, 15). Sy posisie het duidelik ' $n$ biskoplike karakter gedra (Plomp, Stelling IV). In Genéve was hy voorsitter van die predikante-vergade- 
ring en het besluite geneem. Kampschulte merk op dat die samewerking van Calvyn en die Raad Genéve meer as vroeër biskopstad gemaak het (412).

Calvyn aanvaar dat die kerk verskyn op die plek waar herders en leraars die Woord en Sakramente bedien en die tug van die Woord bedien. Die kerk kan en moet dus aan die merktekens van die ware kerk geken kan word. (Inst. IV, i, 4-12; iii, 4.5.6). Predikers moet gelei deur die Heilige Gees (Milner, 142) gedurig in prediking, kategese en huisbesoek die gelowige vertroos, versterk, opbou, vermaan, opwek tot verootmoediging en skuldbelydenis, veral ten tye van sware nood (Inst. IV, i, 22; xii, 14.15.17; Kampschulte, 406v). Elke herder moes in Genéve daartoe 'n ampseed neem (vgl. art. 15-19, Geneefse KO 1560, A. D. Pont, Klasaantekeninge UP, Historiese Agtergronde van ons Kerklike Reg. Tekste met Aantekeninge, Deel I, p. 32v). Besondere sorg is aan die eenheid in en suiwerheid van die leer (GKO 1560, Art. 20-22, Pont, 33v) bestee deur behoorlike tugoefening onder die predikante gestel (GKO, t.a.p., art. 23-34). Die opmerklike is dat slegs predikante oor predikante tug toegepas het. Die predikant (VDM) het egter toesig oor die ouderlinge en diakens gehad (Inst. IV, iii, 12.13; iv. 1). Die predikante is die eintlike opsiener. Boon sê die VDM „is bij Calvijn een uitgesproken episkopale figuur; hij is bischop van de locale kerk" (Boon, 81). Van Ginkel oordeel dat Boon verkeerdelik meen dat Calvyn die opsiener van die kerk (,leke") skei. „Het gaat hem niet om de status, maar om het functionering van cen roeping.... het gaat er veel meer om, dat de Heer zelf in dit ambt functioneert in zijn gemeente. Uiteindelijk gaat het veel meer om het werk, dat gedaan moet worden, dan om een preciese afbakening van de ambten" (Van Ginkel, 147).

Boon argumenteer dat Calvyn se opvatting dat slegs predikante Woord en Sakramente mag bedien en enigste draers van die apostoliese is, aandui dat Calvyn nie beoog het dat die ouderlinge (presbiteriaal) moet regeer en dat daar gelykheid tussen predikante en "regeer-ouderlinge" moet wees nie (Boon, 130v, 136, 201v; Van Ginkel 145). Die predikant noem Calvyn „biskop" en hy pas die Bybelse name opsiener, ouderling, herder en dienaar op hom toe (Inst. IV, iii, 8). Die predikant se posisie in die kerk kan met dié van 'n konstisionele monarg vergelyk word (Boon, 201v). Die patroon is in Baptistiese en Kongregasionalistiese kerke nagevolg. Tog moet goed verstaan word dat Calvyn anders as in biskoplike stelsels, die biskop (en gewoonlik meer as een predikant of biskop) uitsluitend aan die plaaslike kerk verbind het (Boon, 204) en geen biskop in ' $n$ oorkoepelende kerkstruktuur ken nie. Anders as by Rome wys Calvyn vir elke biskop (predikant) sy eie plaaslike kerk aan. Hy bly verbonde aan die gemeente wat hom beroep het en die diens waartoe hy beroep is (Inst. IV, iii, 7; v. 5, 7, 11; Kampschulte, 401).

Calvyn waarsku teen heerssug by predikante wat oor gewetens van gelowiges wil heers en aan hulle voorskrifte wil gee wat nie regstreeks aan die Woord van God ontleen is nie (Inst. IV, x, 6, 7; 
xii, 21). Calvyn se „biskoplike” beskouing van die predikant geld nie sy ,amp", persoon of status nie, maar berus op die diens van die Woord in sover hy dié Woord bedien. Geen predikant kan daarom biskop (opsiener) buite sy eie kerk oor ander gemeentes wees nie (Boon, 204).

\section{Die invloed van Bucer op Calvyn}

Bucer het groot invloed op Calvyn se opvatting oor die kerklike dienste gehad (Van Ginkel, 115v; W. van't Spijker, De ambten bij Martin Bucer, 1970, Kampen). Die Ordonnances Ecclesiastiques van 20.11.1941 in Genéve toon dit duidelik aan. Net soos Bucer moes Calvyn egter ook terdeë met die wense van die Raad van Genéve rekening hou (Plomp, 189). Die Geneefse Kerkorde (vgl. Pont t.a.p.) gee dus nie Calvyn se gedagtes suiwer weer nie.

\section{Die doktore-diens}

Op sterkte van die profete-amp, in aansluiting by die predikantediens en sentrale plek wat die diens van die Woord in die daarstel en daarwees van die kerk (gemeente) beklee, onderskei Calvyn naas die herders en leraars wat die Woord en Sakramente en tug bedien, leraars wat die Skrif moet uitlê (Inst. IV, iii, 4) en die gelowiges in die heilige leer moet onderrig sodat die suiwerheid van die Evangelie nie deur onkunde of verkeerde opvattings geskaad word nie. Aan hulle was die onderrig van die jeug, die opleiding aan die Gimnasium en Akademie van dienaars van die Woord en burgerlike ampsdraers opgedra. Hulle dienste was intiem gekoppel aan die Skoolorde van 1559 (Pont, 37v, GKO 43-47). Hierdie leraars was van kerkregering uitgesluit om onderrig te kan gee en kom met die profete van die OT ooreen. Hulle was dus leraars maar nie herders nie. Die herders kom weer meer met die apostels ooreen (Inst. IV, iii, 5.6).

\section{Die diens van diakens}

In sy Institusie handel Calvyn verskillende male oor die diakens in die Vroeë Kerk en verval van die diakonaat in die Roomse Kerk. In die kerk is "twee ampte": amp van regering en amp van versorging van armes (Inst. IV, iii, 8,12,13; iv, 1). Hy onderskei twee soorte diakens nl. vir die versorging van armes en dié vir krankeversorging (Inst. IV, iii, 9). Die versorging van die predikante soos in die Vroeë Kerk (Inst. IV, iv, 5) wys hy nie aan diakens toe nie, waarskynlik omdat die Raad van Genéve dit behartig het. Boon oordeel dat Calvyn die band tussen diaken en sakrament deurgesny het, sodoende met die apostoliese tradisie gebreek het en die diaken op "social welfare" afgestem het (136v). Die Geneefse KO bepaal dat die Raad van Genéve ook diakens as sy verteenwoordigers aanstel om selfs op koste van die Raad die hospitaal en armversorging onder toesig van die predikante en ouderlinge te bestuur (vgl. Pont, $39 \mathrm{v}$, art. 56-67).

Teen hierdie agtergrond kan die hedendaagse verleentheid met die diaken uit die verwarring van weleer verklaar word. Vandag is daar verskil oor wat die diakendiens inhou. In sommige SA Kerke 
word hy as ,ampsdraer" in die kerkraad soos 'n opsiener betrek, 'n soort hulp-ouderling terwyl die ouderling slegs 'n hulp vir die bedienaar van die Woord is. Moontlik het onduidelikhede in Calvyn se kerkreg tot hierdie situasie gelei.

\section{Die regeer-ouderlinge}

Calvyn praat eers oor die predikant as biskop wat die Woord bedien en die kerk regeer (Inst. IV, iii, 4-8) en dan voeg hy by: daar is net twee ampte wat altyd bly, nl. die regering en die versorging van die armes. So moet daar uit die volk ouderlinge gekies word om saam met die biskoppe toesig te hou oor die lewe van die lidmate en die tug uit te oefen (Inst. IV, iii, 8 verwys na Rom. $12: 8$ ). So kom die ouderlinge saam as 'n raad vir die kerk om tug te oefen soos in elke stad 'n raad bestaan. Sommige ouderlinge het die Woord bedien terwyl ander alleen oor die gemeente toesig gehou het (Inst. IV, xi, 6).

Calvyn is nie heeltemal duidelik oor die verhouding van die predikant as biskop en die ouderlinge as regeerder nie. In die Vroeë Kerk beklee die ouderlinge die primêre posisie en uit hulle geledere is predikante gekies (Inst. IV, iv, 1). Hy noem almal wat in die kerk regeer, sonder onderskeiding of rangorde, ouderlinge. Tog beperk hy die naam „biskop" tot die bedienaars van die Woord.

Die ontwikkeling van die ouderling-amp by Oecolampadius, Bucer en Calvyn kan gesoek word in die behoefte om heerskappyvoering van predikante te temper, om die gemeente volgens Matt. 18:17 ordelik by die tugoefening (ekskommunikasie) te betrek en selfs om direkte inspraak van burgerlike owerhede in die selfstandige kerklike dissipline op kerklike erf in te perk. Die Klein Raad het in Genéve ouderlinge vir 'n jaar benoem. Die wat goed regeer het kon daarna herkies word. In 1561 is verkry dat die benoeming op voordrag van die predikante sou geskied. Die Raad was dus indirek deur benoemde ouderlinge by die kerkraad vir regspraak betrek.

Die regeer-ouderling kom op uit die beginsel dat daar in die kerk onderlinge toesig van die gelowiges moes wees. Die ouderlinge verteenwoordig die gemeente as orgaan van God in die tugoefening. In Genéve het hulle tegelyk die Klein Raad verteenwoordig. Om tirannie te voorkom, moet die ouderlinge met medewete en toestemming van die gemeente regeer (Plomp, 88v, 172v, 180). Ganoczy verwyt Calvyn egter dat hy die diens nie op die algemene priesterskap van die gelowiges nie (Van Ginkel, 148) maar op 'n ius divinum fundeer.

Die ouderlinge is vir Calvyn „Funktionäre Christi” en nie „leke” ampsdraers of demokratiese organe van die gemeente nie. Hulle verteenwoordig die gemeente net in so ver hulle die sedelike taak wat die Wet van God op die gemeente lê in terme van die totum ecclesiae corpus uitvoer (Bohatec, 495v). Calvyn wou die ,kollegialiteit" van die ouderlinge en predikante handhaaf en het daarmee die onderskeiding van clerus en leke deurbreek. Die ouderling kom aan die een kant uit die gemeente „demokraties" naas die predikante maar tegelyk so eie aan Calvyn ook aristokraties t.o.v. die gemeente te staan. Tog was die ouderling by Calvyn nie gelyk aan 
die predikant nie en hulle het weinig vir die leiding van die kerk in Genéve in vergelyking met die predikante beteken (Van Ginkel, 149v).

Elke ouderling het ' $n$ wyk ontvang alwaar hy oor die lewe van elkeen moes toesig hou en gereeld huisbesoek doen. Hulle ampseed by die Raad bepaal dat hulle getrou teen onreëlmatighede sal vermaan en wanneer nodig onpartydig openbare sonde en hardnekkigheid aan die kerkraad (konsistorie) sal berig sodat die stad in goeie orde bewaar word (Pont, 38v, GKO, Art. 48-55; Van Ginkel, $117 \mathrm{v}$; Plomp, 83, 194). Die roeping tot huisbesoek van die ouderlinge was by uitstek die middel om die kerklike dissipline te handhaaf (Plomp, 199). Die aangif by die kerkraad is 'n sekondêre fase van sy bediening. Die ouderling regeer dus kragtens roeping tot ouderling en nie uit hoofde van sy sitting in die kerkraad nie.

Calvyn aanvaar basies dat die ouderling ook van God geroep word om daadwerklik toesig oor die geloof en lewe van die gelowiges te hou (Inst. IV, ii, 10-15). Tog staan dit soos 'n paal bo water dat die ouderlinge van Calvyn hoegenaamd nie die presbiters van die Joodse of van die vroeë christelik-heleense gemeenskappe was nie. Daarvoor was hulle van die administrasie en van die bediening van die Woord en Sakramente, onderskeidelik, uitgesluit (Van Ginkel, 83-94, 144-148; vgl. Calvyn self, Inst. IV, iv, 2.3). Calvyn het egter 'n sekere afronding aan die ouderlingamp gegee, die Bybelse gegewens i.v.m. kerkregering weer relevant gemaak en 'n basis gelê waarop Calvinistiese kerke die ouderlingamp in eie omstandighede verder kon ontwikkel (Van Ginkel, 142). As sodanig is invloed van Calvyn in SA Kerke m.b.t. ouderlingamp merkbaar. Die feit dat die „ouderling” egter dikwels as ,leke"-ampsdraer en ondergeskik aan die predikant (biskop) geplaas of behandel word, mag toegeskrywe word aan die grondleggende betekenis wat die diens van die Woord in Calvyn se Institusie ingeneem het en die feit dat hy eers by Bucer die idee van regeerouderling ontwikkel het.

Die Confession de Foi 1559 maak van superintendente melding, maar nie die Kerkorde van 1561 nie. Van Ginkel temper daarom Boon se opvatting dat Calvyn basies episkopaals dink. Hy waarsku egter om nie die ouderling by Calvyn te verabsoluteer en dan Calvyn te laat sê „wat men zelf denkt” (Van Ginkel, 145v).

Twee, drie of vier ampte

Wanneer iemand skerp tussen amp en diens onderskei lyk dit soms asof Calvyn net twee (Inst. IV, iii, 8) en dan weer drie ampte (Inst. IV, iv, 1) en tog bogenoemde vier dienste aanvaar. Hy praat o.a. van die ,amp" van die leraars as diens (Inst. IV, iii, 4). Die Skrif skei nie amp en diens nie en Calvyn gebruik dit ook deurgaans sinoniem. Eintlik kwalifiseer die begrip „diens" sy ampsbegrip en neem hy amp as ,waardigheid" of posisie nie as sy vertrekpunt nie.

\section{DRIEERLEI GESAG IN DIE KERK}

Christus regeer sy kerk. Die kerk is die ryk waar Hy deur sy Woord regeer (Inst. IV, ii, 4; vi, 9). Die Heilige Gees verleen 
die mag nie aan mense nie, maar deur hulle diens oefen die Woord wat bedien word mag en gesag uit (Inst. IV, viii, 2). Die mag is dus geestelik en dienend van aard en word deur die Woord van God begrens (Inst. IV, viii, 4-9). Die gelowiges is deur Christus vrygemaak. Hulle mag deur geen enkel voorskrif van mense in hulle gewete buite die Woord van God om gebind word nie (Inst. IV, $x, 1)$. Deur die Woord en Gees kan elke gelowige die wil van God ken en Hom dienooreenkomstig dien (Inst. IV, $x, 3.4 .5$ ). Binne hierdie omraming het die Kerk die mag om te leer, om te regeer en om wette te maak (Inst. IV, viii, 1).

Die mag om te leer kom neer op die gesag om leerstellings neer en uit te lê. Daarvoor is sinodes nodig. Die gesag van die sinode word egter uitsluitlik bepaal deur die vraag of die uitspraah met die Woord van die Here ooreenstem (Inst. IV, viii, 1.2.4.5.8). Konsilies het geen eie gesag nie maar kan slegs volgens die Woord van God die leer vasstel. Konsilie-uitsprake moet gedurig op die skaal van die Woord geweeg word (Inst. IV, ix, 9). Die voorgangers moet slegs „Mund Gottes” wees (Bohatec, 516). Die Geloofsbelydenis wat die kerk konstitueer, is dus slegs 'n weergawe van wat God in die Woord leer.

Die mag om wette te maak op sterkte van 1 Kor. 14:40 is ewe begrens. Die reëls wat God in sy Woord gee, moet streng gehandhaaf word. Die ander is egter ,middelmatig" en alleen nodig wanneer dit die ,welwese" godsdiens, eendrag, orde en vrede van die kerk bevorder (Inst. IV, x, 27.28.30; Bohatec, 516, 531). Calvyn se „Formalprinzip" verleen aan kerklike bepalinge bindende outoriteit wanneer dit aan die Skrif ontleen is. Rieker noem dit ten onregte 'n wettiese trek by Calvyn om soos Zwingli slegs te behou wat God uitdruklik gebied (vgl. Bohatec, 383v). Kerklike reëls wat buite die Skrif om gewetens bind en gelowiges beswaar, is ' $n$ vorm van tirannie in stryd met die grondgebod van die liefde (Baur, 64: Bohatec, 386v). Die orde moet nie in allerlei beuselagtighede soos o.a. die vraag of 'n vrou met ongedekte hoof in die gemeente mag kom gesoek word nie (Inst. IV, $x, 29.30 .31$ ). Kerklike bepalinge moet nuttig en weinig in getal wees en duidelik die opbou van die kerk op die oog hê (Inst. IV, x, 32).

Die gesag om reg te spreek kom op uit die roeping om die sleutelmag te hanteer soos Christus dit self sou doen (Boon, 52; Komm. Matt. 16:19; 18:18). Die werklike kerkregering kom neer op „disciplines of morals" (Milner, 175). Die regspraak is van totaal ander aard as die burgerlike (Inst. IV, xi, 1). Die ekskommunikasie is plig omdat die persoon hom self in leer of lewe buite die kerk gestel het. Die spiere of senuwees wat die kerk bind, is alreeds in die onderlinge vermaning in die gemeente aanwesig. Wanneer lemand na die vermaning en na die ouderling op huisbesoek nie luister nie, moet hy by die konsistorie (kerkraad) aangegee word om indien hy hom nie bekeer nie van die kerk afgesny te word (Inst. IV, xii, 1.2). Die middel moet egter met omsigtigheid, barmhartigheid en onderskeiding tussen ligter en swaarder sondes gebruik word (Inst. IV, xii, 3.4.6) om die eer van God te handhaaf, goeie 
sedes in die gemeente te bewaar en die sondaar tot berou en bekering met die oog op sy behoud te bring (Inst. IV, xii, 5). „Kerkelijke rechtsplegen.... ze ist rechtsplegen.... geestelijke rechtsplegen.... Er wordt niet geoordeelt na menselijke normen, maar uitsluitend ,ex Lege Dei'; de zonden worden bestraft ,ex verbo Domini" (Plomp, 72). Indien een of 'n paar biskoppe die ban sou toepas, mag dit tot heerskappyvoering en tirannie lei. Met die oog op die kerklike dissipline wat die sleutelmag hanteer, rig Calvyn dan die konsistorie of kerkraad in.

T. Whiterow tipeer presbiteriale kerkregering vanuit die begrip „presbytary" (The Apostolic Church, 1967, p. 66) as regering deur die „elders .... in their assembled capacity". Wie die kerkraad so as basis van Calvyn se kerkregering verstaan, misken sy Skriftuurlike begrip van roeping en diens, sy aansluiting by die vroeë kerk dat 'n persoon in sy diens kragtens roeping van God gesag uitoefen en dat strukture soos 'n kerkvergadering nooit die grondslag en uitgangspunt van sy kerkregering vorm nie. Die ouderling is tot diens van regering geroep. Sekondêr of in tweede vlak van regering kom ouderlinge bymekaar in kerkraad vir die ingrypende handeling van tug wat op ekskommunikasie mag uitloop.

\section{DIE KERKRAAD (KONSISTORIE)}

Soos daar 'n Raad vir die burgerlike regering van die stad is, so moet daar ook 'n selfstandige kerklike raad (senaat) wees alwaar die biskoppe en ouderlinge die kerk kan lei in die kerklike regspraak (Inst. IV, xi, 3.5.6.; xii, 7.8.9.11). Die handelinge van die kerkraad is handelinge van die kerk (Plomp, 85). Gevolglik moes die medewerking en toestemming van die gemeente steeds verseker word (Bohatec, 422-424). Die naam ,konsistorie" is ontleen aan die eertydse biskoplike tribunaal waarin kerklike en burgerlike aspekte m.b.t. huweliksake hanteer is (Plomp, 182v). Bohatec (546) verwerp Sohm se bewering dat Calvyn wêreldse regspraak ingevoer het.

Calvyn het in 1541 'n kerkraad as voorwaarde aan die Raad van Genéve gestel nie om die beginsel van kerkraad nie, maar om selfstandige en ongehinderde geestelike dissipline in die kerk te verseker. Uit 'n brief van Calvyn in Maart 1542 aan Myconius blyk dat die konsistorie vir Calvyn "der Stolz der Genfer Kirche" in diens van die koningskap van Christus was (Kampschulte, 442). Die vyf predikante met twaalf ouderlinge deur die Raad van Genéve benoem, het weekliks onder voorsitterskap van een van die ouderlinge vergader om oor die geestelike orde in Genéve te waak. Met gesag van die Raad kon hulle iemand daag om te verskyn en wie weier aan die Raad oorgee (Pont, 56, GKO, Art. 151-153). Die prosedure van tughandelinge is in die Dordtse Kerkorde van 1619 opgeneem.

Die Raad van Tweehonderd het op 5.2 .1560 besluit dat die burgemeester, kragtens die wesensonderskeid van kerklike en burgerlike mag, voortaan nie meer sy ampstaf as simbool van gesag na die kerkraadsvergadering sal bring om die kerkraad te lei nie (GKO, t.a.p. Art. 168). 
Calvyn aanvaar dat een kerk deur meer as een predikant bedien word. Die predikante was verplig om weekliks mekaar op te skerp oor die eendrag in die leer. Die dienaars van omliggende dorpe moes minstens eenmaal per maand so 'n byeenkoms bywoon (Pont, 33, GKO Art. 20, 21). Om die goeie orde en eenstemmigheid in die leer, prediking, kategese, huisbesoek en pastoraat te bewaar, sal twee verteenwoordigers van die Raad en predikantevergadering, onderskeidelik, jaarliks elke kerkplek binne die Geneefse kerk besoek en oor die diens van die predikante toesig uitoefen. Hierdie visitasie dra hoegenaamd nie 'n geregtelike karakter nie, maar die resultate word aan die predikantevergadering meegedeel met die oog op onderlinge vermaning (GKO, t.a.p. Art. 20-38). Bepaald anders as wat Calvyn dit sou wou gehad het, maar eie aan die corpus christianum, het die Raad van Genéve die finale gesag oor die predikante gevoer (GKO, t.a.p.; art. 27).

Die feit dat die predikante naas die kerkraad vergader het, sonder dat daar vir die regeer-ouderlinge 'n eie ampsamekoms was, onderstreep die unieke posisie van die predikant as bedienaar van die woord. Dit is duidelik dat die predikant nie sy opdrag van die kerkraad, 'n kerkvergadering of konstitusie ontvang nie. Hy is en bly geroepe dienaar van Christus aan die gemeente verbonde.

\section{KERKE IN KERKVERBAND}

Die kerk is in die wêreld, binne ' $n$ territoriale en politieke eenheid, byvoorbeeld as die kerk van Genéve, d.w.s. kerk binne die natuurlike geïndentifiseerde menslike samelewing van Genéve. In Strassburg het weer op etniese gronde 'n Franse gemeente afsonderlik voorgekom.

Elke kerk tree selfstandig t.o.v. die leer op totdat 'n krisis 'n konsilie gewens maak. Waar biskoppe van verskillende kerke saam vergader, beraadslaag hulle beter. Samekomste van die opsieners van Genéve, Basel e.a. was gebruiklik (Inst. IV, ix, 13). Die gesag van Konsilies is egter feilbaar en moet op die skaal van die Woord geweeg word (Inst. IV, ix, 8, 9; Milner, 149). Calvyn verwerp die Roomse leer dat die Konsilie beeld van die kerk is en die biskoppe dic waarheid waarborg. (Inst. IV, ix, 3). Die kerk bestaan nie in 'n vergadering van regeerders nie (Inst. IV, ix, 7). Geen konsilie kan aanspraak maak dat hy onfeilbaar deur die Heilige Gees gelei word en beeld van die kerk is op sterkte waarvan hy gewetens kan bind nie (Inst. IV, viii, 10.13; ix, 1.2.3.). Dit is duidelik dat kerkvergadering (kerkraad, sinode) plaasvind met die oog op beter bediening en beter kerk-wees en nie om die kerk te konstitueer of voor te skryf nie.

\section{ENKELE VERKENNINGSKONTOERE VAN INVLOED OP SA-KERKE}

Die Institusie en kommentare van Calvyn het ongetwyfeld 'n direkte en in sommige opsigte selfs bepalende rol gespeel op die Konvent van Wezel 1568 en die Nederlandse kerkregtelike ontwikkeling van 1571 tot 1619 , wat kristalliseer in die Dordtse Kerkorde. Waar dié Kerkorde aan die Kaap onder die eienaardige corpus 
christianum administrasie van die VOC slegs in die gemeentes en veral m.b.t. die tug ' $n$ rol kon speel, was daar in die gemeentes invloed van Calvyn werksaam. Engelstalige kerkgemeenskappe is my in hierdie opsig minder bekend. Ek waag egter om te beweer dat bostaande ook waar is t.o.v. Baptiste en Kongregasionaliste. By die Presbiteriane het waarskynlik reeds 'n sterker geinstitusionaliseerde „presbytary" en kerkstruktuur op 'n konstitusionele basis 'n rol gespeel.

\section{Calvyn se uitgangspunt in die Ordonnansie van God}

Dit is tipies "calvinisties" om van die ordonnansie van God uit te gaan. Die beginsel het in die verskillende Afrikaanse en Engelse kerkgemeenskappe tot diep in die 20ste eeu 'n belangrike rol gespeel sodat opvattings oor leer, lewe en beskouing bewustelik en regstreeks aan die Wil van God soos geopenbaar in die Bybel getoets is. Optrede van die NG en Anglikaanse Kerke in die vorige eeu teen leerdwalings is in die Hooggeregshof betwis. Elders het ek die eerbied vir God en kenmerk om in alles "naar Gods Woord" te probeer leef, onder 'n bepaalde Afrikaner gemeenskap, breër as die latere Gereformeerde Kerk, aangetoon (vgl. Die Doppers in SA $1760-1899$, hfst. 2 en 3 ).

\section{Christus deur die Heilige Gees Hoof van die Kerk}

Hierdie opvatting van Calvyn word in die Afrikaanse Kerke offisiëel geleer en bely (vgl. Heid. Kat. Sondae 21, 48; Ned. Geloofsbelydenis 31,32 ). In die eenvoudiger, patriargale en landelike gemeenskappe het daadwerklike rekening met die hoofskap van Christus soos in die voorgaande paragraaf aangeraak, kerklike opvattings en verantwoordelikheid gevorm. Die liturgiese en moontlik die inhoudlike bediening van die Woord, belydenis van geloof, ontvang van sakramente, staan tot diep in die 20ste eeu sentraal in die Afrikaanse kerklike lewe. Namate die Liberalisme van die 19de eeu, skoolonderwys, meer predikante en gemeentes, sinodale verbande en gesentraliseerde sinodale organisasie asook verskillende kerkgemeenskappe na vore getree het, het dié basiese blik op die kerk as eenheid rondom Woord en Sakramentbediening vervaag voor die idee dat die kerk godsdienstige genootskap, 'n bepaalde institusionele eenheid onder sinodale beheer is. Dit mag een rede wees waarom sektes soms teen die SA-kerke aanval. Die nadruk op kerkraads- en veral sinodebesluite, teologie en predikante, kan die indruk wek dat die mens en sy verhouding tot Christus, die verantwoording aan Christus en die Heilige Gees in SA kerklike situasie deur die institusionele gesentraliseerde opset verplaas is. Daar is waarskynlik 'n onversoende spanning in SA kerke tussen die opvatting dat die kerk genootskap en daarteenoor dat die kerk volk van God is.

3. Die onderskeiding van politieke en kerklike regering

Tot 1804 was die losstaande kerke in SA feitlik kerkgemeenskappe soos op die skepe van die HOIK. Aan die een kant het hulle plaaslik vryheid en geestelike selfstandigheid onder die versorgende hand van die VOC en die Klassis Amsterdam geniet. Aan die ander kant was hulle institusioneel van die eiesoortige Neder- 
landse koloniale bestel afhanklik. Na 1806 kom die Anglikane met hulle opvatting dat kerk en staat intiem verwant is (caesaropapie). Met behulp van die Kerkorde van De Mist (1804) speel die politieke owerheid ' $n$ dominerende rol ook in die Kaapse Kerk. Die kerk word selfs as instrument vir anglisering en neutrale staatsskoolonderwys gebruik. Die Skotse Presbiteriane kom in reaksie binne die Kaapse Ned. Geref. Kerk en slaag om die kerk betreklik selfstandig van die Goewerneur in Ordonnansie 7 van 1843 te mak. Die Ned. Herv. Kerk in die ZAR wil sedert 1853 kerk van die staat wees.

Die eerste Gereformeerde Kerke in Transvaal, Vrystaat en Kaapkolonie stel hulle in 1859 en 1860 egter by die onderskeie owerhede as „Vrye" kerke bekend. Hulle ywer saam met Engelse Independentiste vir die „vrywillige beginsel" sodat skeiding tussen kerk en staat t.o.v. die NG, NH en Anglikaanse Kerke in die Republieke en Kolonies deurgevoer word. Hier het Liberalisme en invloed van Calvyn waarskynlik in dieselfde rigting gewerk. SA kerke het egter dikwels van die „Christelike” staat verwag om met wetgewing die samelewing te heilig.

\section{Die kerk as plaaslike pmeumatiese organisme}

Calvyn se kerkbegrip het waarskynlik die losstaande kerke onder die VOC-bewind beheers. Die tug-gevalle waar die kerkraad van Genéve teen opgetree het (Plomp, 218-232), tipeer die tipies Afrikaanse en Engelse puriteinse opvattings oor sedes en godsdienstige verantwoordelikheid binne die gemeente. Die belewenis van die plaaslike kerk as organisme van eenheid in leer en lewe het ook gelei tot botsings met kerkbesture en talle gevalle waar gemeentes van bepaalde kerkgemeenskappe afgeskei het. Merkwaardig genoeg het die afgeskeie gemeente altyd aanvaar dat hy kerk van Christus is, al het hy van ' $n$ bepaalde kerkgemeenskap afgeskei. Tog is lierklike krisisse gewoonlik nie beoordeel met Calvyn se erns en vraag of daar eenheid in die leer en gehoorsaamheid aan die Woord is nie. ' $n$ Bepaalde kerkstruktuur is dikwels as norm geneem.

Die nawerking van die Roomse institusionalisme, die Nederlandse formeel-regtelike inslag en veral die opkoms van die 18de eeuse rasionalistiese idee van vrywillige menslike assosiasies het Calvyn se dinamiese kerkopvatting in Suid-Afrika grotendeels verdring. By A. Kuyper kom die onderskeiding kerk as instituut en kerk as organisme na vore. $\mathrm{H}$. Berkhof sluit hierby aan (Christelijk Geloof, 1973, 413). Die kerk word vandag feitlik uitsluitend as instituut, verteenwoordig in sy professionele klerus en vergaderinge, verstaan. Kuyper se ,kerk as organisme" verdwyn in die sand, of moet in allerlei Christelike instituutjies (verenigings, partye ens.) geinstitusionaliseer word. Die verlies van die Skrifmatige (Calvyn se „Formalprinzip") pneumatiese organisme in ruil vir die institusionele kerkgemeenskap (of kerke as kerkverband, kerkgenootskap) bring waarskynlik die krisis mee waarmee talle kerke vandag worstel. Dit skyn asof die Baptiste en Kongregasionaliste, hoewel hulle die monargale biskop plaaslik behou, iets van Calvyn se dinamiese en 
organiese kerkbegrip volgens die beweging na of van die Woord af, vasgeklem het. Met sy opvatting dat tug die gemeente veral suiwer om die nagmaaltafel saambring, kon Calvyn die verwyt van die Anabaptiste teen die verwaarlosing van geloof by die gemeente suksesvol beantwoord (vgl. W. Balke: Calvijn en de Doperse Radikalen, 1973). Het die vermoë nie vandag verlore gegaan nie?

'n Rapport aan die GES te Nimes 1980 sê dat klerikalisering en institusionalisering van die kerk ,robs believers of their personal responsibility and treats them as minors who have to listen to the voice of Mother Church .... We admit, however, that as far as the biblical data are concerned, the distinction (instituut en organisme, B.S.) seems hardly applicable, for the simple reason that the New Testament writings hardly ever single out the church in its institutional form" (RES 1980, The Church and its Social Calling, 26).

Die invloed van Calvyn het klaarblyklik ten opsigte van die essensiële en mees fundamentele aspek van kerkbegrip in die postcalvinistiese kerke wêreldwyd verlore gegaan. Die gemeente as organisme (geïnstitueerd en buite instituut) speel byna geen rol in die huidige kerklike opset nie. Alle aandag word toegespits op die abstrakte eenheid, 'n ,kerk", 'n gesentraliseerde gemeenskap, wat gewoonlik 'n bepaalde identiteit met 'n sentrale institusionele program en identiteit verteenwoordig. Die ,kerk" as eenheid of genootskap word organisatories en institusioneel verstaan. Die ,kerk" verplaas vandag die Skrif as „Formalprinzip". Die beslissende vraag is nie wat sê die Skrif nie, maar wat sê die kerk? Die nagmaal word vandag daarom ook eerder vir (L.W.) „lidmate” van die betrokke institusionele eenheid as vir ' $n$ eenheid van gelowiges wat die Wil van God in leer en lewe gehoorsaam, bedoel. Oefen gemeentes nog enigsins onderling self tug met die Woord uit? Dit gaan vandag skynbaar meer om die struktuur as om die kwaliteit van die kerk as liggaam van Christus.

\section{Die vier dienste of ampte}

Formeel word die vier dienste van Calvyn in talle SA Kerke erken. In die liturgiese bevestigingsformuliere is die invloed van Calvyn duidelik merkbaar. Soos by Calvyn beklee die predikant gewoonlik die posisie van ,biskop”. Waar kerke met net een predikant taamlik algemeen voorkom, kom die teorie van presbiteriale kerkregering in praktyk op dié van 'n konstitusionele monargie binne elke gemeente neer. Die aanspraak dat die „ampte” vandag gelyk is, is meer teorie as praktyk en vrae oor die gerigtheid van die diens van ouderling en diaken onderskeidelik ontkom vandag nie aan verwarring nie.

\section{Die Drieërlei magte in die kerke}

Calvyn se onderskeiding tussen mag om te leer, mag om te regeer en mag om wette te maak het grootliks in onbruik geraak. Eerstens word leergesag feitlik nie beoefen nie en word by die Konfessies van die Reformasie volstaan. Die wetgewende en regsprekende magte word vandag meesal volgens sekulêre regsbeginsels van die kerk as menslike samelewingsverband en struktuur afgelei. 
Die kerklike struktuur is dan nie meer bedienaar van 'n mag nie, maar self die mag wat regeer en wette maak. Calvyn se onderskeiding tussen essensiële en middelmatige sake word nie meer gehandhaaf nie. Die wil van die sinode verplaas die Wil van God. Die kerklike bevoegdheid van 'n sinode is feitlik onbeperk. Dit mag selfs oor middelmatige sake voorskrifelike besluite neem wat „lidmate" bind.

\section{Die Kerkraad en Sinode}

Calvyn se invloed strek nie verder as die formele daar-wees van die kerkraad nie. In 'n enkele geval waar die predikant(e) en ouderlinge saamkom vir sencura morum of tugoefening voor nagmaal herinner dit nog aan Calvyn. Anders as by Calvyn word die sinode vandag dikwels gesien as beeld van die kerk. Die Kerkraad en/of Sinode word vandag taamlik algemeen sui generis as vergadering of verteenwoordiger (orgaan) van die kerk, korporasie of genootskap as wetgewende en/of regsprekende gesag aanvaar. Kerkrade moet hulle skik na Sinodes ter wille van ,,eenheid" en ,eenvormigheid" sodat 'n abstrakte kerkgemeenskap tot sy reg kom. In kerkregtelike teoretisering mag een die lokale kerk, 'n ander die sinode en 'n derde selfs beide as genootskaplike vertrekpunt neem.

\section{EPILOOG}

Formeel en tradisioneel is dit maklik om die invloed van Calvyn op die kerkregering in Kerke in SA te veronderstel. Die sentrale plek wat die prediking in kerk-wees inneem, is duidelik van Calvyn afkomstig. Wanneer die kerkregtelike situasie egter krities en wesenlik evalueer word, is Calvyn se invloed waarskynlik kleiner as die invloed van Rooms Kanonieke reg, Engelse of Nederlandse institusionalisme, Romeins-Hollandse regsbeginsels, rasionalistiese filosofie, Lutheranisme en veral die Genootskapsreg van die 18de eeu waarin J. J. Rousseau die beginsels van menslike outonomie, natuurreg en sosiale kontrak (genootskap) ontwikkel het. Die feit dat die corpus christianum van die 16de tot 20 ste eeu so 'n steurende en tegelyk steunende rol t.o.v. kerkinstituering gespeel het, mag verklaar waarom daar geen suiwer kerkregtelike tradisie van Calvyn in SA beskryf kon word nie.

Gelewer voor die Internasionale Calvyn-kongres te Pretoria, Augustus 1980. 